Received: 23.03.2016.

UDK: 78-052-053.6

Original scientific work

\title{
LISTENING TO MUSIC AND MUSIC PREFERENCES IN EARLY ADOLESCENCE
}

\author{
Ina Reić Ercegovac \\ Faculty of Humanities and Social Sciences \\ University of Split \\ inareic@ffst.hr \\ Snježana Dobrota \\ Faculty of Humanities and Social Sciences \\ University of Split \\ Sara Surić \\ Faculty of Humanities and Social Sciences \\ University of Split
}

\begin{abstract}
Music plays an important role in the life of adolescents. Dealing with music represents a very important free-time activity during adolescence, while by listening to music or performing music adolescents can satisfy a range of needs, both personal and those of social nature. Therefore, this paper presents the results of research on musical taste and listening to music habits in early adolescence. We hypothesised that students generally like listening to music and that they mostly prefer domestic and foreign popular music. It was also assumed that older students, on average, listen to music more than younger students and that there is a significant relation between certain personality traits and preferences of certain musical styles. We used The Eysenck Personality Questionnaire for children together with an instrument designed for this study that consists of two questionnaires - Listening to Music Questionnaire and Musical Performers Preferences Questionnaire. The results showed that students generally like listening to music and that they usually listen to music one hour per day. As expected, students prefer popular music, especially domestic pop, pop-folk and foreign pop. Neuroticism was correlated with preferences of turbo-folk music, popular domestic and foreign rock music, while other relations with personality traits were not established. Younger students assessed
\end{abstract}


more important role of music education in the formation of musical taste, therefore, we indicated implications for music lessons at an early school age.

Keywords: early adolescence, music, musical preferences, listening to music, personality, music classes

\section{INTRODUCTION}

\section{Early adolescence}

Adolescence is a developmental period of transition from childhood to adulthood and is marked by significant changes in the physical, psychological, cognitive and social aspects. It begins with puberty, or physical changes that occur between 10 and 13 years of age, somewhat earlier in girls than boys. Adolescence can be divided into several stages - early, middle and late. Early adolescence covers the age between 10 and 14 years. The main characteristics of this period are physical changes and processes of accepting them. In addition, early adolescent begins to think about the meaning of life and the passage of time. New relationships they seek for are relationships with peers and friends (Rudan, 2004). Adolescence is the time of de-idealization of parents where young person leaves familiar ways of thinking, childhood interests and attitudes in search for new ones. Therefore, this is the period when feelings of loneliness and alienation usually occur. Due to conflicts with the authorities, most often parents, adolescents often have the feeling that the environment does not understand or support them. That is why they mostly turn to their peers and time spent with them significantly increases, compared to the time spent with their family (Vizek Vidović et al. 2003). Peer interactions become more intimate based on self-discovery and sharing personal experiences (Lacković-Grgin, 2006; Dopp and Cain, 2012). Erikson (1968) in his life-span perspective also emphasizes the important role of peers in psychosocial development. In cognitive terms, early adolescent can separate from the current and foreseeable problems and is able to solve hypothetical problems. Thanks to the development of abstract thinking, the main features of thinking become hypothetical deductive reasoning and systematic problem solving. According to Erikson (1968), cognitive development in this stage is the basis for psychosocial development because young people, thanks to new cognitive qualities, can deal with the possibilities, not just current and concrete. This allows them to ask questions about future life, about what they can become and what can they do - questions that are inherent to identity crisis which characterizes the period of adolescence (Erikson, 1968) and refers to the attempt of a young person to gain a sense of identity in terms of beliefs, attitudes, professional and other features. 


\section{Early adolescents and music}

Music plays an important role in personal and social life of adolescents. Data from the USA suggest that adolescents on average listen to music two to three hours per day (Rideout, Foehr and Roberts, 2010). The importance of music in the life of an adolescent is reflected in its social functions such as self-presentation, and the presentation of thinking, attitudes and values of the individual (Dehyle, 1998, Knobloch and Zillman, 2003), which is especially important during the identity formation in adolescence (North and Hargreaves, 1999). A number of studies have tried to determine why music is so important in the life of young people and how adolescents actively use music to meet a range of their needs - social, emotional and developmental (Arnett, Larson and Offer, 1995; Rubin, 1994). Such studies usually assume that music preferences reflect the values, conflicts and developmental problems that young people face during adolescence. North, Hargreaves and O'Neill (2000) investigated the importance of music in the sample of English adolescents and the reasons why they listen and perform music. The results showed that dealing with music helps them in self-presentation and satisfies their emotional needs. Tarrant and North (2000) explored the reasons why English and American teens listen to music and they found three factors: self-actualization, meeting the emotional needs and meeting the social needs. Musical preferences certainly play a significant role in forming adolescent friendships (Rentfrow and Gosling, 2006; Selfhout, Branje, ter Bogt and Meeus, 2009) which can be explained in different ways. According to the Social Identity Theory (Tajfel, 1978) individuals acquire social identity of the group they belong to and, consequently, adopt similar preferences and habits as other group members in order to strengthen self-esteem and feelings of belonging to a group. Since adolescent musical preferences often form the basis of peer group (Brown, Eicher and Petrie, 1986; Selfhout, Reading, ter Bogt and Meeus, 2009), and musical preferences are considered an important dimension of social identity in adolescents (Tarrant, North and Hargreaves, 2001), adolescents usually have similar musical preferences as they adopted them from each other. According to the Similarity-Attraction Hypothesis (Byrne, 1971) individuals are mostly attracted to people who have similar attitudes, values, behaviours and personality traits (Morry, 2005). Since the musical preferences of adolescents are often reflected through their clothing, hair styles and patterns of behaviour associated with a particular musical style (Christenson and Roberts, 1998), it is possible that the similarity of musical preferences plays an important role in forming friendships and peer groups. According to the Uses and Gratification Approach, individuals choose different media depending on personality traits (Arnett, 1995; Arnett et al. 1995). Consequently, the listeners gravitate toward a certain type of music because of their personality traits, problems and needs, reflected by selected music. Therefore, preferences of young people for the alternative, heavy metal or rap music may be a reflection of the rebellious mood and resistance to authority. Preferences for such musical styles outside the mainstream reflect the values, conflicts and developmental tasks of adolescents (Schwartz and Fouts, 2003). That kind of music is close to younger people, primarily due to fast and loud sounds of guitars, bass and drums, expressing a wide range of emotions that are 
close to young people. Furthermore, lyrics in musical genres, such as heavy metal or alternative music, include moral relativism and opposition to authority (Reić Ercegovac and Dobrota, 2011). Hansen and Hansen (1991) also point out that the preference of such musical expression is associated with hyper sexuality, antisocial behaviours and rejection of authority. Adolescents use music for regulating emotions in a way that it distracts them from trouble, thus, avoiding undesirable emotional states and moods.

In Croatia, there is no many research on musical taste, preferences and habits of listening to music in late childhood or early adolescence. Vidulin-Orbanić (2012), for example, on a sample of students in elementary and high schools showed that students mostly listen to popular music, followed by rock, electronic and hip-hop music. Studies conducted in the middle adolescence (15-18 years of age) showed also a clear preference for popular music (Dobrota and Reić Ercegovac, 2009), while research on older adolescents, average age about 20 years, showed a clear preference for complex musical styles (alternative, heavy- metal and classical music) and conventional musical styles (Reić Ercegovac and Dobrota, 2011). In a sample of primary school students, from first to fourth grade, Mikić and Rukavina (2006) found that the most preferred musical style is popular music, chosen by $55 \%$ of students, and rock music, chosen by $40 \%$ of students. Folk music was chosen as the most preferred one in $25 \%$ of the students. Research by Dobrota and Curković (2006) showed that 73\% of students of fourth and 38\% of eighthgraders have a positive attitude towards classical music. Also, students of fourth and eighth grade in the same study showed a higher degree of preference for classical music of romanticism compared to the contemporary music of the 20th century. There were also age differences found in preferences for traditional music of Egypt and China which were more positively assessed by the younger students. The authors concluded that younger children are more open to different, unfamiliar music, since they still don't have strict attitudes towards music or musical taste fully developed. Results by Šulentić Begić (2009) showed that among pupils of the first three years of primary school, $75 \%$ of them loves classical music while only $25 \%$ expressed a negative attitude. Among $95 \%$ of students who listen to music at home, the author found that $63 \%$ listens to classical music, $45 \%$ popular music, about $18 \%$ of students stated they listen to jazz, and 33\% traditional folk music. Lyrics were more important than melody for over $57 \%$ of students, while others found melody to be more important than lyrics. Considering listening to turbo-folk music, it is interesting that early school-aged participants do not listen that kind of music, while study conducted on high school students (Šulentić Begić and Begić, 2013) has shown that turbo-folk immediately followed popular music considering popularity.

\section{The relationship between musical preferences and personality traits}

Great contribution to the study of the relationship between personality traits and musical preferences was provided by studies of Rentfrow and Gosling $(2003,2006,2007)$, which elucidated the role of individual characteristics in musical preferences and listening to music. With regard to personality traits, their results showed that the preference for music with cheerful rhythms and vocals is significantly associated with extraversion, 
while the preference for complex and classical music is associated with intellect or openness to experience (Rentfrow and Gosling, 2003). Pearson and Dollinger (2004) found that extraversion is associated generally with musical interests and preferences for pop/rock music. Preferences for energetic and dance music, usually found in extraverts, can be explained by the fact that extraverts use music for stimulation and activation, particularly during monotonous activities (McCown, Keiser, Mulhearn and Williamson, 1997). In addition, studies have shown that the background music interferes with other cognitive processes significantly more in introverts than in extraverts (Furnham and Strbac, 2002). Some authors have pointed out the connection between extraversion and preferences for rock music, especially hard-rock music as a specific direction within rock music (Daoussis and McKelvie, 1986). Delsing, ter Bogt, Engels and Meeus (2008) during the three-year follow-up of over two thousand adolescents identified four interpretable dimensions of musical preferences (rock, elite, urban music, pop-dance music) and established a consistent connection between personality traits and musical preferences, as well as their stability over a three year period.

\section{AIM OF THE RESEARCH, RESEARCH PROBLEMS AND HYPOTHESIS}

Research of musical preferences of children and adolescents are of multiple importance. First, music plays an important role in the lives of adolescents, as a mean of satisfying emotional needs, as a determinant of membership of a particular social group, as a feature of group identity, or as a mean for regulating mood. Furthermore, earlier studies have shown that the musical preferences of adolescents are significant predictors of psychosocial adjustment and antisocial behaviours (ter Bogt, Keijsers and Meeus, 2013). It is, therefore, very important to what music are children and adolescents exposed to during the formation of their musical taste, in a family context, institutional ones or in a group of peers. Although most research on musical preferences of young people dealt with later adolescents or emerging adults, it is useful to explore the musical preferences in an earlier age because research shows that preference of certain genres of music from early adolescence remain relatively stable throughout the whole adolescent period (Mulder, ter Bogt, Raaijmakers and Vollebergh, 2007; Delsing, ter Bogt, Engels and Meeus, 2008). Furthermore, since the majority of studies that investigated the relationship between personality traits and musical preferences was conducted on late adolescents or emerging adults, one of the goals of this study was to examine whether common patterns of this relationship (e.g. association between extraversion and popular/ dance music) apply to early adolescent population as well. Finally, the aim of this study was to investigate the habits of listening to music in early adolescence and their musical tastes in form of preferences of certain musical performers/styles.

In order to achieve these objectives, the research attempts to answer the following issues:

1. What is the habit of listening to music in early adolescence?

2. What type of music early adolescents listen to in their free time? 
3. What is the attitude of the early adolescents towards folk music and world music?

4. Is there a connection between personality traits and musical taste in early adolescence?

We hypothesised that early adolescents would mostly prefer domestic and foreign popular music and that they would have positive attitude towards listening to music in their free time. It was expected that the older students would spend more time listening to music per day, compared to younger students and that they would prefer, compared to younger students, foreign popular or rock music. With regard to the relationship between personality and musical taste, it was expected that there would be a significant correlation between extraversion and preferences for popular music.

\section{RESEARCH METHODS}

\section{Participants and research procedure}

A total of 164 participants took part in the study. There were $\mathrm{N}=91$ students in fourth grade and $\mathrm{N}=73$ in sixth grade. Research was conducted during second semester of 2014/2015 school year in several elementary schools in Split area and Mali Lošinj. Participation in the study was voluntary and anonymous. Completing the questionnaire took 30 minutes on average and was conducted during regular school hours with the prior consent of the school principals and parents. The collected data were analysed using statistical application STATISTICA12.

\section{Instruments}

The Eysenck Personality Questionnaire for children and an instrument designed for this survey, which consisted of two parts - Listening to Music Questionnaire and Musical Performers Preferences Questionnaire were administered.

Listening to Music Questionnaire consisted of seven closed questions and was used to collect data on the habits of listening to music, such as: the type of music participants listen to (popular, classical, folk), listening to music in free time (yes/no), attitude towards folk music (negative, indifferent, positive), the amount of time spent listening to music per day (less than one hour, one hour or more than an hour), familiarity with world music (never heard of, heard of but do not listen, sometimes listen, often listen), the impact of music classes on musical taste (yes/no).

Musical Performers Preferences Questionnaire consisted of 47 artists from different genres for whom participants assessed how much they like them or how often they listen to them. These were assessed on a scale of 5 degrees where 1 meant doesn't listen to him/ her ever, and 5 meant love listening to him/her. It should be noted that in the preparation 
of the questionnaire experts from the fields of psychology, music art and music pedagogy were consulted. Domestic performers were selected due to their presence in the media and radio stations while foreign performers were selected due to their current popularity at the time of research. Artists from older generations were also included in the questionnaire although their music is not currently at the top of the listenership and popularity, but can be considered as known to the general population at large. Finally, the questionnaire included performers of turbo-folk music concerts that are held in the Republic of Croatia, and are present in other media.

The results of the factor analysis carried out by the method of principal components with varimax normalized rotation and psychometric features of formed sub-scales are shown in Table 1.

Table 1. Factor structure of Musical Performers Preferences Questionnaire and psychometric characteristics of subscales

\begin{tabular}{|l|c|c|c|c|c|c|c|}
\hline performer & F1 & F2 & F3 & F4 & F5 & F6 & F7 \\
\hline Severina & .19 & .04 & .08 & $\mathbf{. 6 7}$ & .05 & .08 & .22 \\
\hline Jole & .17 & .20 & .16 & $\mathbf{. 3 5}$ & .05 & .00 & .13 \\
\hline Jelena Rozga & .16 & .00 & .05 & $\mathbf{. 7 9}$ & .07 & .05 & .14 \\
\hline Magazin & .17 & .12 & .07 &. $\mathbf{7 6}$ & .04 & .21 & .01 \\
\hline Nives Celzijus & .25 & .22 & .18 & $\mathbf{. 5 6}$ & .11 & .07 & .13 \\
\hline Lidija Bačić & .16 & .15 & .01 &. $\mathbf{7 0}$ & .04 & .12 & .06 \\
\hline Maja Šuput & .08 & .31 & .04 & $\mathbf{. 6 0}$ & .14 & .05 & .05 \\
\hline Colonia & .05 & .19 & .05 &. $\mathbf{3 7}$ & .25 & .20 &. $\mathbf{3 1}$ \\
\hline Mejaši & .05 & .28 & .02 & .39 & .04 & .04 & .16 \\
\hline & & & & & & & \\
\hline Nina Badrić & .11 & .18 & .10 &. $\mathbf{3 6}$ & .12 & .14 &. $\mathbf{4 9}$ \\
\hline Tony Cetinski & .05 & .16 & .03 & .26 & .05 & .13 & .75 \\
\hline J. Houdek & .08 & .25 & .06 & .03 & .16 & .03 &. $\mathbf{6 9}$ \\
\hline & & & & & & & \\
\hline Željko Bebek & .02 & $\mathbf{. 6 2}$ & .02 & .14 & .19 & .01 & .11 \\
\hline Dražen Zečić & .12 &. $\mathbf{7 4}$ & .24 & .19 & .08 & .06 & .00 \\
\hline Giuliano & .05 & $\mathbf{. 6 4}$ & .00 & .27 & .16 & .28 & .16 \\
\hline Mate Mišo Kovač & .04 &. $\mathbf{7 9}$ & .02 & .07 & .02 & .07 & .26 \\
\hline Mladen Grdović & .03 &. $\mathbf{7 6}$ & .18 & .03 & .00 & .07 & .13 \\
\hline Oliver Dragojević & .03 & $\mathbf{. 5 2}$ & .02 & .01 & .07 & .09 &. $\mathbf{5 0}$ \\
\hline & & & & & & & \\
\hline Mile Kitić & .73 & .09 & .23 & .10 & .08 & .10 & .08 \\
\hline
\end{tabular}




\begin{tabular}{|c|c|c|c|c|c|c|c|}
\hline Dara Bubamara & .73 & .08 & .13 & .22 & .02 & .07 & .06 \\
\hline Mitar Mirić & .87 & .02 & .15 & .00 & .10 & .04 & .01 \\
\hline Dragana Mirković & .71 & .02 & .13 & .09 & .02 & .07 & .07 \\
\hline Lepa Brena & .33 & .12 & .13 & .20 & .08 & .15 & .01 \\
\hline Ceca & .40 & .09 & .17 & .20 & .11 & .10 & .05 \\
\hline Miroslav Ilić & .53 & .24 & .05 & .02 & .24 & .21 & .18 \\
\hline Ana Nikolić & .72 & .00 & .29 & .16 & .09 & .08 & .04 \\
\hline Boban Rajović & .88 & .02 & .11 & .01 & .04 & .22 & .04 \\
\hline Nedeljko Bajić Baja & .85 & .04 & .05 & .12 & .04 & .13 & .00 \\
\hline Seka Aleksić & .62 & .02 & .12 & .25 & .01 & .01 & .03 \\
\hline Hanka Paldum & .74 & .19 & .16 & .18 & .12 & .12 & .03 \\
\hline Haris Džinović & .64 & .16 & .14 & .23 & .13 & .00 & .03 \\
\hline Avicii & .23 & .11 & .31 & .17 & .62 & .08 & .04 \\
\hline Robbie Williams & .10 & .20 & .22 & .01 & .53 & .45 & .02 \\
\hline Pharell Williams & .08 & .21 & .16 & .01 & .72 & .32 & .04 \\
\hline Bruno Mars & .10 & .12 & .10 & .13 & .73 & .17 & .22 \\
\hline Shakira & .00 & .16 & .00 & .46 & .49 & .06 & .35 \\
\hline Michael Jackson & .02 & .11 & .24 & .02 & .20 & .45 & .36 \\
\hline Queen & .14 & .10 & .25 & .04 & .14 & .72 & .14 \\
\hline Tina Turner & .10 & .06 & .03 & .25 & .29 & .68 & .07 \\
\hline Mick Jagger & .16 & .08 & .50 & .10 & .10 & .50 & .07 \\
\hline James Brown & .18 & .28 & .24 & .21 & .22 & .58 & .12 \\
\hline Iggy Pop & .09 & .03 & .71 & .12 & .16 & .03 & .02 \\
\hline Jim Morrison & .07 & .10 & .53 & .14 & .04 & .49 & .01 \\
\hline Kurt Cobain & .27 & .07 & .83 & .01 & .05 & .14 & .04 \\
\hline Elton John & .26 & .15 & .84 & .04 & .09 & .18 & .03 \\
\hline Bruce Springsteen & .25 & .14 & .83 & .08 & .14 & .10 & .07 \\
\hline Janis Joplin & .28 & .15 & .80 & .07 & .08 & .16 & .03 \\
\hline Cronbach $a$ & .93 & .85 & .90 & .85 & .76 & .79 & .74 \\
\hline$M(s d)$ & $\begin{array}{l}20.69 \\
(8.51) \\
\end{array}$ & $\begin{array}{r}14.12 \\
(5.03)\end{array}$ & $\begin{array}{c}9.60 \\
(4.74)\end{array}$ & $\begin{array}{l}23.92 \\
(7.04)\end{array}$ & $\begin{array}{r}14.29 \\
(5.02) \\
\end{array}$ & $\begin{array}{l}11.35 \\
(4.59)\end{array}$ & 7.84 \\
\hline
\end{tabular}




\begin{tabular}{|r|c|c|c|c|c|c|c|}
\hline$(2.84)$ & & & & & & & \\
\hline range & $13-65$ & $6-30$ & $6-30$ & $9-45$ & $5-25$ & $5-25$ & $3-15$ \\
\hline $\begin{array}{r}\text { average inter-item } \\
\text { correlation }\end{array}$ & .55 & .49 & .67 & .40 & .40 & .43 & .49 \\
\hline
\end{tabular}

Musical Performers Preferences Questionnaire showed relatively pure factor structure with one item having high saturation on one factor, but low on others. Several items significantly saturated more than one factor (Colonia, N. Simone, Oliver, R. Williams, Shakira, Michael Jackson and J. Morrison), but were included in the factor they saturated the most. Due to the resulting factor structure, several sub-scales with high reliability coefficients ranging from Cronbach $\alpha=.74$ to Cronbach $\alpha=.93$ were formed. The first factor relates to the turbo-folk music, the other to pop music, the third to rock music, the fourth to domestic pop-folk music, the fifth to pop, sixth to pop-rock, and the seventh to domestic pop music. The overall results for preferences of these musical styles have been formed as the average assessment on items that made up subscales.

For measuring personality traits, the EPQ Junior - Eysenck Personality Questionnaire for children (Eysenck and Eysenck, 1994), designed for children aged 7-15 years, was administered. Participants have to answer to all questions by yes or no. Scoring is done by using the scoring key which gives total scores for three subscales - extraversion, neuroticism and psychoticism. Table 2 shows the results of participants in these personality traits. In order to explore whether participants differ in personality traits in terms of age, three t-tests were conducted and their results are shown in Table 2. Sixth graders, compared to fourth-graders, reported significantly higher degree of neuroticism, while there were no significant age differences in other two personality traits.

Table 2. Average results on EPQ Junior and age differences in personality traits

\begin{tabular}{|l|c|c|c|c|c|c|c|}
\hline & $\mathrm{M}$ (4. r.) & $\mathrm{M}$ (6. r.) & sd (4. r.) & sd (6. r.) & $\mathrm{t}$ & $\mathrm{df}$ & $\mathrm{p}$ \\
\hline Psychoticism & 2.64 & 2.67 & 2.38 & 2.11 & -.06 & 162 & .95 \\
\hline Extraversion & 16.91 & 16.68 & 2.48 & 3.17 & .51 & 162 & .61 \\
\hline Neuroticism & 10.63 & 13.19 & 3.83 & 3.75 & -4.30 & 162 & .00 \\
\hline
\end{tabular}

\section{RESULTS AND DISCUSSION}

Almost all participants (95\%) stated they prefer to listen to music (155 of 164). Regarding the time spent on listening to music, $43 \%$ of participants listen to music for an hour a day, $29 \%$ less than one hour per day, and $27 \%$ of participants listen to music more than one hour per day. There is a significant difference between the students of fourth and sixth grade $(\chi 2=6.20, \mathrm{df}=2, \mathrm{p}=.045)$ where, contrary to the expectations, younger students listen to music more than older ones. It was expected that by growing up and 
moving through adolescence, music would occupy more time in adolescents' life with peak reaching in medium/late adolescence, but the results of this study showed different. It is possible that older students are preoccupied with school work and other obligations which leave them less time to listen to music. However, it should be noted that the total time of listening to music per day was relatively small since only $25 \%$ of participants stated they listen to music more than one hour per day.

Among the types of music participants listen to, over $85 \%$ opted for popular music and only $7.3 \%$ chose classical and folk music which is considerably less than in some previous studies (Mikic and Rukavina, 2006; Šulentić Begić, 2009). When asked what their attitude towards folk music is, 30\% of participants expressed a positive attitude, 50\% negative and $20 \%$ neutral. The analysis showed that more positive attitude towards folk music have older students compared to students in fourth grade ( $\chi 2=7.15, \mathrm{df}=2, \mathrm{p}=.028$ ). It can be assumed that the older students are more familiar with different musical styles, including folk music which can contribute to a more positive attitude as it is well known that familiarity of music is related to musical preferences (Peretz, Gaudreau and Bonnel, 1998, North and Hargreaves, 2008; Dobrota and Reić Ercegovac, 2009; Dobrota, 2012). When interpreting these results with half of the respondents having a negative attitude towards folk music, raises the question of folk music perception and its understanding by the participants. Specifically, since certain elements of folk music are combined with popular music which ultimately leads to a different contemporary musical styles of questionable success and quality, it is questionable what participants meant when answering the questions concerning folk music. Methodological lack of refinement that it is a traditional folk music in question certainly puts limits to the possibility of concluding on attitudes towards folk music, especially because these results are quite different from results of previous studies on attitudes toward folk music in primary school-aged children.

When asked about the familiarity of world music, $36 \%$ of participants said they had never heard of the term, $21 \%$ of participants reported that they were familiar with the term, but that they do not listen to that kind of music, $27 \%$ of participants sometimes listens to world music, and even $16 \%$ of participants often listens that kind of music. There weren't any significant age differences found $\left(\chi^{2}=3.48, \mathrm{df}=3, \mathrm{p}=.324\right)$. The resulting data could serve teachers to enrich the students' musical genres that in our country are not sufficiently known. Earlier research (Dobrota and Curković, 2006) has shown relatively positive attitude of fourth-graders for music of China and Egypt showing that students should be exposed to different musical styles and music of different cultures in order to have a chance to develop and shape their musical tastes.

Finally, when asked about the impact of musical classes in school on their own musical taste, half of the participants believed that music education has a significant impact on the musical taste (49.39\%), and half of the participants stated that such influence does not exist (50.61\%). Significant age differences were found $(\chi 2=16.83, \mathrm{df}=1, \mathrm{p}=.000)$, showing that fourth-grade students, compared to the older ones, in higher percentage believe that music education has an impact on musical taste. Students of fourth grade usually meet with classical music just through music lessons in school, therefore, assess the impact of musical lessons on individuals' musical taste as more important. On the other hand, sixth 
graders, given the developmental status and challenges of adolescents they face, generally have more negative attitude towards school (Raboteg Šarić et al., 2009) and its role in life, compared to younger students. It is possible that such attitude toward school affected their assessments of school influences on musical taste formation. It should be noted that one study conducted on adolescents in upper grades of elementary schools and high schools showed that less than one-fifth of students during class likes to listen to classical music, and that only $12 \%$ of students outside of class listen to music from educational CDs (Vidulin, 2013), which also suggests the small possibility of music lessons influencing the musical taste of students.

With the aim of examining the differences in musical preferences of different musical styles between students of fourth and sixth grade, repeated measures analysis of variance was conducted. The results are shown in Figure 1 and in Table 3.

Figure 1 Preferences for listening different musical styles

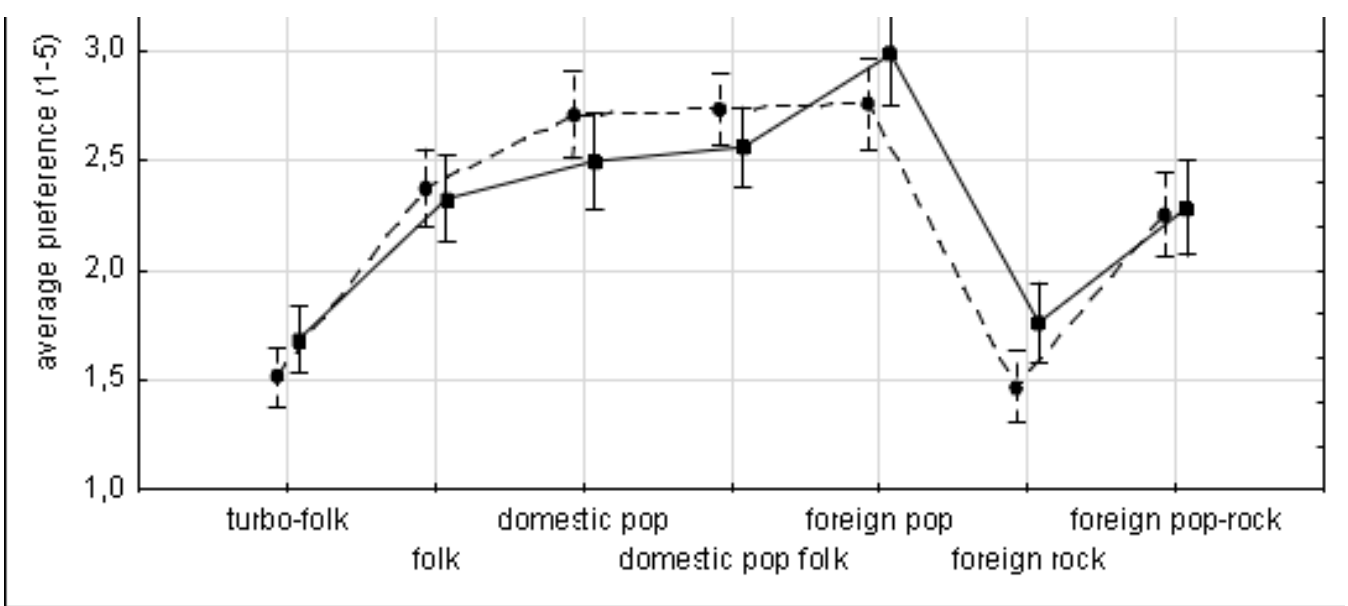

Table 3. Results of repeated measures ANOVA for testing age differences in preferences for different musical styles

\begin{tabular}{|l|r|c|c|c|}
\hline & Musical style & $\mathrm{M}$ & sd & $\mathrm{N}$ \\
\hline $4^{\text {th }}$ grade & Turbo-folk & 1.51 & .60 & 91 \\
\cline { 2 - 5 } & Folk & 2.38 & .83 & 91 \\
\cline { 2 - 5 } & Domestic pop & 2.71 & .96 & 91 \\
\cline { 2 - 5 } & Domestic pop-folk & 2.74 & .75 & 91 \\
\cline { 2 - 5 } & Foreign pop & 2.76 & .97 & 91 \\
\cline { 2 - 5 } & Foreign rock & 1.47 & .64 & 91 \\
\cline { 2 - 5 } & Foreign pop-rock & 2.26 & .91 & 91 \\
\hline
\end{tabular}




\begin{tabular}{|r|r|c|c|c|}
\hline $6^{\text {th }}$ grade & Turbo-folk & 1.69 & .71 & 73 \\
\cline { 2 - 5 } & Folk & 2.33 & .85 & 73 \\
\cline { 2 - 5 } & Domestic pop & 2.50 & .92 & 73 \\
\cline { 2 - 5 } & Domestic pop-folk & 2.56 & .82 & 73 \\
\cline { 2 - 5 } & Foreign pop & 2.98 & 1.04 & 73 \\
\cline { 2 - 5 } & Foreign rock & 1.76 & .92 & 73 \\
\hline Foreign pop-rock & 2.28 & .93 & 73 \\
\hline Fage & .19 & $\mathrm{df}=1,162$ & .661 \\
\cline { 2 - 5 } & Fagex musical style & 3.45 & $\mathrm{df}=6,972$ & .002 \\
\cline { 2 - 5 } & & & & \\
\cline { 2 - 5 } & & & & \\
\hline
\end{tabular}

Participants expressed the greatest preference for domestic and foreign popular music (Figure 1), followed by folk music and foreign pop-rock, while the lowest degree of liking was obtained for the foreign rock music and turbo-folk. The analysis showed that these differences are significant $(\mathrm{F}=88.84, \mathrm{p}=.000)$. Among all of the offered music performers, most preferred was Shakira $(M=3.65)$, Bruno Mars $(M=3.08)$, and from local performers Jelena Rozga $(M=2.97)$ and Tony $(M=2.90)$. The results which suggest that turbo-folk is the least preferred musical genre is in accordance with results obtained by Šulentić-Begić (2009). However, it should be noted that this sample was somewhat younger than the sample of our research. Obtained results can also be compared to research conducted by Dobrota and Reić Ercegovac (2009), which also confirmed that the musical taste of students is mostly oriented toward popular music, specifically domestic and foreign pop music. Results of Vidulin-Orbanić (2012) showed that adolescents most often listen to popular music with girls expressing higher preferences for pop music than boys. Popular music being the most preferred in adolescence should not be surprising given the fact that adolescents are mostly exposed to that musical genre, via different media, and the fact that it's the kind of music designed to meet the expectations of the younger population. A significant interaction effect $(\mathrm{F}=3.45 ; \mathrm{p}=.002)$ of gender and musical styles can be attributed to the relationship between age and foreign and domestic popular music which shows that younger students prefer local or domestic popular performers, compared to foreign ones, while older students prefer foreign performers compared to local popular performers (Figure 1). This was to be expected for several reasons. First, older students spend more time on the Internet and social networks (Pregrad et al., 2012), therefore, they are more exposed to foreign music, especially popular music hits of foreign performers. Second, due to developmental reasons, older students, compared to younger ones, want to present themselves as followers of world musical trends to a greater extent. That usually contributes to their "popularity" in a group of peers, therefore, keeping track of popular foreign music (and other medias; movies, etc.) becomes more important as they move through adolescence. 
Table 4 shows the correlation matrix of variables included in the study. It is evident that there is a significant relationship between neuroticism and preferences for turbofolk music, popular domestic and foreign rock music. Specifically, participants with higher scores on neuroticism reported a greater tendency for listening turbo-folk music and foreign rock music, and have reported smaller preferences for domestic pop. The association between neuroticism and listening to music mainly refers to the emotionalregulating role of music were emotionally unstable individuals use music for the purpose of emotional regulation and mood regulation more than stable ones (ChamorroPremuzic and Furnham, 2007). It is possible that these musical styles (turbo-folk and foreign rock) better fulfil this role for emotionally unstable individuals. Extraversion and psychoticism did not proved to be significantly associated with listening to any kind of music. These results are not consistent with results of previous studies that identified a significant relationship between extraversion and preferences for dance-rhythmic musical styles, including popular music (Reić Ercegovac and Dobrota, 2011). It is possible that on a sample of early adolescents, the relationship between personality traits and musical preferences is not the same as in the older age groups (older adolescents). However, due to relatively small sample size used in this study, further studies are needed to explore the relationship between personality and musical preferences. In addition, further research should include other personality characteristics, outside the Eysenck model in order to elucidate associations between musical preferences and personality. 


\begin{tabular}{|c|c|c|c|c|c|c|c|c|c|c|c|c|c|c|c|c|c|}
\hline 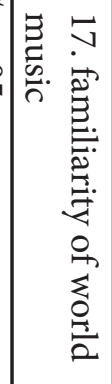 & 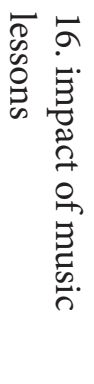 & 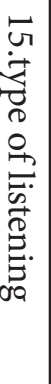 & 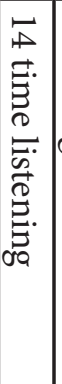 & 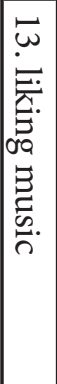 & 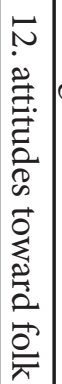 & 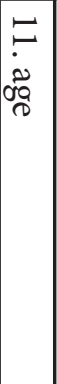 & 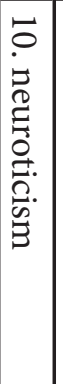 & 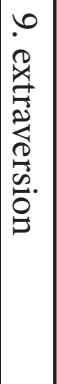 & 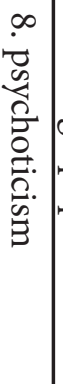 & 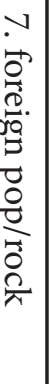 & 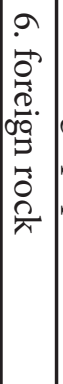 & 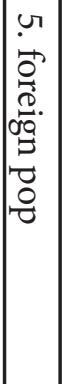 & 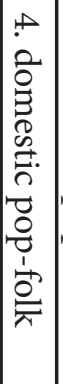 & 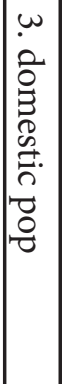 & $\begin{array}{l}N \\
\dot{O} \\
\sigma^{\prime}\end{array}$ & 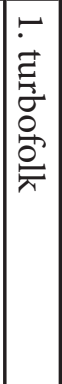 & \\
\hline$\underset{\sim}{\tilde{a}}$ & $\dot{\circ}$ & ì & $\dot{\infty}$ & $\dot{i}_{n}^{\prime}$ & $\dot{I}^{\prime}$ & $\dot{\omega}_{\omega}$ & $\dot{\sigma}_{*}$ & $\dot{8}$ & $\dot{n}^{\prime}$ & $\underset{\sim}{\dot{w}}$ & $i_{*} \dot{A}_{*}$ & $\dot{\omega}_{\stackrel{+}{\infty}}$ & $\begin{array}{l}i_{\infty} \\
\infty \\
*\end{array}$ & $\underset{*}{\sim} \underset{*}{\sim}$ & \begin{tabular}{|l}
$\dot{i}$ \\
$\tilde{u}$ \\
$*$
\end{tabular} & & $\bullet$ \\
\hline$\underset{*}{\sim}$ & $\dot{v}$ & $\dot{\sim}$ & $\dot{\sim}_{\substack{\infty \\
*}}^{\prime}$ & $\dot{\infty}$ & $\begin{array}{l}\dot{\tilde{\tilde{\sigma}}} \\
\sigma_{*}\end{array}$ & $\dot{\omega}$ & $\dot{\text { Oे }}$ & $\dot{\omega}$ & 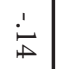 & $\underset{*}{\underset{\sim}{w}}$ & $\begin{array}{l}\dot{\sim}_{*} \\
\sigma_{*}\end{array}$ & $\underset{*}{\stackrel{i}{y}}$ & $\dot{i}_{*}$ & $\underset{*}{\stackrel{i}{*}}$ & & & 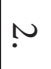 \\
\hline$\dot{\tilde{\alpha}}_{*}$ & $\dot{.}$ & $\dot{\mathrm{\omega}}$ & $\dot{\dot{a}}$ & $\dot{\sim}$ & 'ं & $\dot{\square}$ & $\dot{\dot{a}}$ & $\dot{\dot{v}}$ & i̊ & $\underset{*}{\stackrel{i}{\underset{*}{*}}}$ & $\underset{*}{\stackrel{i}{*}}$ & $\begin{array}{c}i \\
w \\
* \\
*\end{array}$ & $\begin{array}{l}i \\
0 \\
* \\
*\end{array}$ & & & & س. \\
\hline$\stackrel{i}{*}_{*}^{i}$ & $\dot{a}_{*}^{\prime}$ & $\dot{\vec{\sigma}}_{*}$ & 웅 & $\dot{\dot{a}}$ & $\underset{*}{\stackrel{1}{\sim}}$ & $\dot{\check{H}}$ & $\dot{\omega}_{\omega}^{\prime}$ & $\dot{1}$ & 8 & $\dot{w}_{\vec{x}}$ & $\dot{\vec{\sigma}}_{\boldsymbol{*}}$ & $\underset{\sim}{\stackrel{\sim}{*}}$ & & & & & 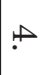 \\
\hline$\vec{\sigma}_{*}$ & 8 & $\underset{\sim}{\stackrel{\sim}{\sim}}$ & '.' & $\dot{\dot{\sigma}}$ & $\dot{\circ}$ & $\Xi$ & 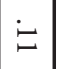 & $\dot{\circ}$ & 它 & స్తి & $\mid$\begin{tabular}{l}
$\stackrel{i}{\sim}$ \\
\multirow{*}{*}{}
\end{tabular} & & & & & & r. \\
\hline$\dot{\omega}$ & $\stackrel{\circ}{\circ}$ & o & $\dot{1}$ & $\dot{\dot{v}}$ & '̇ & 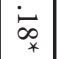 & $\dot{\infty}_{*}$ & $\dot{8}$ & $\dot{\infty}$ & 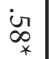 & & & & & & & 9 \\
\hline$\underset{*}{\sim}$ & ட் & $\stackrel{\dot{\prime}}{=}$ & $\dot{\phi}$ & $\dot{1}$ & ì & $\dot{\circ}$ & $\dot{\text { O }}$ & $\dot{8}$ & نे & & & & & & & &.$v$ \\
\hline$\dot{\infty}$ & $\ddot{\sigma}$ & 운 & $\dot{\omega}$ & $\dot{\sigma}_{*}$ & $\dot{I}_{\not{D}}^{\prime}$ & $\dot{\ominus}$ & 오 & نे & & & & & & & & & $\infty$ \\
\hline 웅 & $\dot{\triangleright}$ & $\dot{8}$ & i̊ & $\dot{\text { ci }}$ & $\dot{8}$ & $\dot{1}$ & $\dot{\theta}$ & & & & & & & & & & ๑. \\
\hline$\stackrel{1}{=}$ & $\underset{*}{\stackrel{i}{*}}$ & $\dot{\dot{v}}$ & 它 & $\dot{\omega}$ & $\dot{8}$ & $\underset{*}{i} \underset{*}{i}$ & & & & & & & & & & & 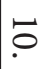 \\
\hline$\dot{8}$ & $\underset{*}{\sim \sim}$ & $\dot{\omega}$ & $\dot{I}^{\prime}$ & $\dot{8}$ & $\dot{8}$ & & & & & & & & & & & & 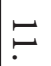 \\
\hline$\ddot{\sigma}$ & 오 & $\dot{\circ}$ & ○ & $\dot{v i}$ & & & & & & & & & & & & & 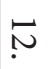 \\
\hline$\dot{v}$ & 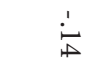 & $\dot{8}$ & 우 & & & & & & & & & & & & & & . \\
\hline ๙ & $\stackrel{1}{=}$ & 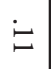 & & & & & & & & & & & & & & & $\rightleftarrows$ \\
\hline 品 & $\stackrel{1}{\perp}$ & & & & & & & & & & & & & & & & $\vec{r}$ \\
\hline$\dot{\circ}$ & & & & & & & & & & & & & & & & & $\vec{a}$ \\
\hline & & & & & & & & & & & & & & & & & $\vec{\jmath}$ \\
\hline
\end{tabular}

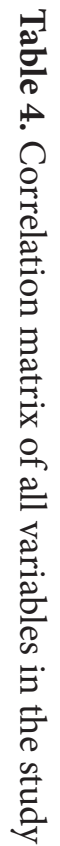


It should be noted that preferences for different musical styles are interrelated, indicating a general tendency to listening to music (correlation coefficients ranged from $\mathrm{r}=.16$ to $\mathrm{r}=.58$ ). It is reasonable to assume that adolescents' preferences and musical tastes are not yet fully formed, but rather in the process of formation. Therefore, they listen to different types of music that are available to them, through different media.

\section{CONCLUSION}

Results of this study showed that there aren't significant differences in musical tastes of students of fourth and sixth grade. Domestic and foreign popular music, including local pop-folk, were assessed as most preferred musical styles in both age groups. Neuroticism proved to be positively associated with the preferences for turbo-folk and foreign rock music while extroversion and psychoticism were not related to the preferences of any musical style. Sixth graders have a more positive attitude towards folk music compared to younger students. Finally, fourth-grade students, on average, spent more time per day listening to music compared to sixth- graders. They also assessed impact of musical school lessons on forming ones musical taste as more important than did older students. This result indicates the importance of the activity of listening to music in the early school age and exposure of children to different musical genres, especially classical music, traditional folk music and music of different cultures, thus, contributing to the development of their musical taste.

\section{REFERENCES}

1. Arnett, J. J. (1995). Adolescent's uses of media for self-socialization. Journal of Youth and Adolescence, 24 (5): 519-533.

2. Arnett, J. J., Larson, R., Offer, D. (1995). Beyond effects: Adolescents as active media users. Journal of Youth and Adolescence, 24 (5): 511-518.

3. Brown, B. B., Eicher, S. A., Petrie, S. (1986). The importance of peer group („Crowd“) affiliation in adolescence. Journal of Adolescence, 9 (1): 73-96.

4. Byrne, D. (1971). The attraction paradigm. New York: Academic Press.

5. Chamorro-Premuzic, T., Furnham, A. (2007). Personality and music: Can traits explain how people use music in everyday life? British Journal of Psychology, 98(2): 175-185.

6. Christenson, P.G., Roberts D.F. (1998). It's not only rock \& roll: Popular music in the lives of adolescents. Cresskill, NJ: Hampton Press.

7. Daoussis, L., McKelvie, S.J. (1986). Musical preference and effects of music on a reading comprehension test for extraverts and introverts. Perceptual and Motor Skills, 62: 283- 289.

8. Dehyle, D. (1998). From break dancing to heavy metal: Navajo youth, resistance, and identity. Youth \& Society, 30: 3-31. 
9. Delsing, M.J.M.H., ter Bogt, T.F.M., Engels, R.C.M.E., Meeus, W.H.J. (2008). Adolescents' music preferences and personality characteristics. European Journal of Personality, 22 (2): 109-130.

10. Dobrota, S. (2012). Uvod u suvremenu glazbenu pedagogiju. Split: Filozofski fakultet Sveučilišta u Splitu.

11. Dobrota, S., Curković, G. (2006). Glazbene preferencije djece mlađe školske dobi. Život i škola, 15-16: 105-114.

12. Dobrota, S., Reić Ercegovac, I. (2009). Glazbene preferencije mladih s obzirom na neke sociodemografske varijable. Odgojne znanosti, 11(2): 129-146.

13. Dopp, A.R., Cain, A.C. (2012): The Role of Peer Relationships in Parental Bereavement during Childhood and Adolescence. Death Studies, 36 (1): 41 - 60.

14. Erikson, E. H. (1968). Identity: Youth and crisis. New York: Norton.

15. Eysenck, H.J., Eysenck, S.B.G. (1994). Eysenckov upitnik ličnosti - EPQ. Jastrebarsko: Naklada Slap.

16. Furnham, A., Strbac, L. (2002). Music is as distracting as noise: The differential distraction of background music and noise on the cognitive test performance of introverts and extraverts. Ergonomics, 45(3): 203-17.

17. Hansen, C.H., Hansen, R.D. (1991). Constructing personality and social reality through music: Individual differences among fans of punk and heavy metal music. Journal of Broadcasting \& Electronic Media, 35(3): 335-350.

18. Knobloch, S., Zillman, D. (2003). Appeal of love themes in popular music. Psychological Reports, 93: 653-658.

19. Lacković-Grgin, K. (2006). Psihologija adolescencije. Jastrebarsko: Naklada Slap.

20. McCown, W., Keiser, R., Mulhearn, S., Williamson, D. (1997). The role of personality and gender in preferences for exaggerated bass in music. Personality and Individual Differences, 23: 543-547.

21. Mikić, K., Rukavina, A. (2006). Djeca i mediji. Zapis - bilten Hrvatskog filmskog saveza. Special edition, assessed: http://www.hfs.hr/nakladnistvo_zapis_detail. aspx?sif_clanci=1604\#.VesgCBHtmkp

22. Morry, M. M. (2005). Relationship satisfaction as a predictor of similarity ratings: A test of the attracion-similarity hypothesis. Journal of Social and Personal Relationships, 22 (4): 561-584.

23. Mulder, J., ter Bogt, T.F.M., Raaijmakers, Q., Vollebergh, W. (2007). Music taste groups and problem behavior. Journal of Youth and Adolescence, 36 (3): 313-324.

24. North, A.C., Hargreaves, D.J. (1999). Music and adolescent identity. Music Education Research, 1: 75-92.

25. North, A. C., Hargreaves, D. J. (2008). The social and Applied Psychology of Music. New York: Oxford University Press.

26. North, A. C., Hargreaves, D. J., O’Neill, S. A. (2000). The importance of music to adolescents. British Journal of Educational Psychology, 70 (2): 255-272.

27. Pearson, J., Dollinger, S. (2004). Music preference correlates of Jungian types. Personality and Individual Differences, 36: 1005-1008.

28. Peretz, I., Gaudreau, D., Bonnel, A-M. (1998). Exposure effects on music preference 
and recognition." Memory \& Cognition, 26: 884-902.

29. Pregrad, J., Tomić Latinac, M., Mikulić, M., Šeparović, N. Iskustva i stavovi djece, roditelja i učitelja prema elektroničkim medijima. Zagreb: Ured UNICEF-a za Hrvatsku. Assessed September 9th 2015. at http://www.unicef.hr/upload/ file/353/176706/FILENAME/Izvjestaj_-_Iskustva_i_stavovi_djece_roditelja_i_ ucitelja_prema_elektronickim_medijima.pdf.

30. Raboteg-Šarić, Z., Šakić, M., Brajša-Žganec, A. (2009). Kvaliteta života u osnovnoj školi: povezanost sa školskim uspjehom, motivacijom i ponašanjem učenika. Društvena istraživanja, 18(4-5): 697-716.

31. Reić Ercegovac, I., Dobrota, S. (2011). Povezanost između glazbenih preferencija, sociodemografskih značajki i osobina ličnosti iz petfaktorskoga modela. Psihologijske teme, 20, (1): $47-66$.

32. Rentfrow, P.J., Gosling, S.D. (2003). The do re mi's of everyday life: The structure and personality correlates of music preferences. Journal of personality and social psychology, 84: 1236-1256.

33. Rentfrow, P. J., Gosling, S. D. (2006). Message in a ballad: The role of music preferences in interpersonal perception. Psychological Science, 17 (3): 236-242.

34. Rentfrow, P.J., Gosling, S.D. (2007). The content and validity of stereotypes about fans of 14 music genres. Psychology of Music, 35(2): 306-326.

35. Rideout, V., Foehr, U., Roberts, D. (2010). Generation M2: Media in the Lives of 8-to 18-Year-Olds. Victoria, Canada: Henry J. Kaiser Foundation.

36. Rubin, A.M. (1994). Media uses and effects: A uses-and-gratifications perspective. In: Bryant, J., Zillman, D. (Eds.). Media Effects: Advances in Theory and Research. Hillsdale, NJ: Erlbaum.

37. Rudan, V. (2004). Normalni adolescentni razvoj. Medix, 52: 36 - 39.

38. Schwartz, K.D., Fouts, G.T. (2003). Music preferences, personality style, and developmental issues of adolescents. Journal of Youth and Adolescence, 32: 205-213.

39. Selfhout, M.H.W., Branje, S.J.T., ter Bogt, T.F.M., Meeus, W.H.J. (2009). The role of music preferences in early adolescents' friendship formation and stability. Journal of Adolescence, 32(1): 95-107.

40. Šulentić Begić, J. (2009). Glazbeni ukus učenika osnovnoškolske dobi. Tonovi časopis glazbenih i plesnih pedagoga, 53: 65 - 74 .

41. Šulentić Begić, J., Begić, A. (2013). Glazbene preferencije učenika I Gimnazije u Osijeku. Međunarodni interdisciplinarni znanstveni skup Kultura, društvo, identitet - Europski realiteti. Osijek, 20. - 21. ožujka 2013.

42. Tajfel, H. (1978). Differentiation between social groups. London: Academic Press.

43. Tarrant, M., North, A.C. (2000). English and American Adolescents' Reasons for Listening to Music. Psychology of Music, 28 (2): 166-173.

44. Tarrant, M., North, A.C., Hargreaves, D.J. (2001). Social categorization, self-esteem, and the estimated musical preferences of male adolescents. The Journal of Social Psychology, 141 (5): 565-581.

45. Ter Bogt, T.F.M., Keijsers, L., Meeus, W.H.J. (2013). Early Adolescent Music Preferences and Minor Delinquency. Pediatrics, 131: 2. doi: 10.1542/peds.2012-0703. 
Assessed September 7th 2015. at www.pediatrics.org/cgi/doi/10.542/peds.2012-0708. 46. Vidulin-Orbanić, S. (2012). Utjecaj glazbene nastave na (glazbenu) kulturu učenika. U: N. Hrvatić i A. Klapan (ur.)., Pedagogija i kultura. Sv. 1., Hrvatsko pedagogijsko društvo, Zagreb, str. 419-430.

47. Vidulin, S. (2013). Propitivanje ostvarenja ciljeva nastave glazbe u kontekstu vremena glazbene hiperprodukcije. Arti musices: Hrvatski muzikološki zbornik, 44 (2): 201226.

48. Vizek Vidović, V., Rijavec, M., Vlahović-Štetić, V., Miljković, D. (2003). Psihologija obrazovanja. Zagreb: IEP.

\section{SLUŠANJE GLAZBE I GLAZBENE PREFERENCIJE U RANOJ ADOLESCENCIJI}

\section{SAŽETAK}

Glazba ima važnu ulogu u životu adolescenata. Bavljenje glazbom predstavlja vrlo zastupljenu aktivnost slobodnog vremena tijekom adolescencije, a slušanje ili izvođenje glazbe adolescentima zadovoljava niz potreba, kako onih osobnih, tako i onih društvene prirode. Stoga su u ovom radu prikazani rezultati istraživanja nekih vidova glazbenog ukusa i navika slušanja glazbe ranih adolescenata. $U$ istraživanje se krenulo od pretpostavke da učenici općenito vole slušati glazbu, da preferiraju domaću i stranu popularnu glazbu, da stariji učenici u prosjeku više slušaju glazbu od mlađih te da postoji povezanost između nekih osobina ličnosti i preferencija određenih glazbenih izričaja. Primijenjen je Eysenckov upitnik ličnosti za djecu te instrument konstruiran za potrebe ovog istraživanja - Upitnik slušanja glazbe i Upitnik preferencija slušanja različitih glazbenih izvođača. Rezultati su pokazali da učenici općenito vole slušati glazbu, da najveći udio sudionika sluša glazbu oko sat vremena dnevno te da preferiraju popularnu glazbu, posebno domaći pop i pop-folk te strani pop. Od osobina ličnosti, jedino se neuroticizam pokazao povezanim s preferencijama turbofolk glazbe, domaće popularne i strane rock glazbe. Mlađi učenici procjenjuju važnijom ulogu glazbene nastave u formiranju glazbenog ukusa pa su u radu naznačene implikacije za glazbenu nastavu u ranoj školskoj dobi.

Ključne riječi: rana adolescencija, glazba, glazbene preferencije, slušanje glazbe, osobine ličnosti, glazbena nastava 